(Provinces of Echizen, Etchu, Wakasa, Yamashiro, Inaba, Shinano, Suruga, Mika wa, Tōtōmi and Kazusa (Tōgane district).

Type: $\delta$ Prov. Shinano, 2. XI. 1911, no. 212 in my collection.

\title{
On the Migration of Certain Birds in Tokyo and the Vicinity. (I).
}

By

Nagamichi Kuroda, D. Sc.

Table of Contents.

I. Introduction.

II. The Anserine Birds.

III. The Ardeine Birds.

IV. The Limicoline Birds.

V. Some Rails, Doves, and Owls.

VI. Some Passerine Birds.

VII. Literature Cited.

I. Introduction.

The aim of this paper is to report the result of observations on the migration of certain birds in Tokyo and the vicinity. Before describing my own researchs a brief summary on this branch of knowledge in Japan proper will be given.

The first accout of the migration of birds in Japan was that of Blakiston and Pryer $(1878,1882)$, while Jouy (1883) wrote the habits of the birds in the country. Temminck and Schlegel give no field-notes. Jules Soller's paper (1889) contains some interesting notes on the birds of Japan and their migrations. Seebohm (1890) was the first to give more correct 
notes with respect to the migration and distribution of the Japanese birds, but he never even visited the islands. Ogawa $(1895,1896,1900,1901,1902)$ reported many interesting facts concernning the habits and migration of our birds at Nikko, Fujiyama, Tokyo, Shizuoka, and Yonezawa, Prov. Uzen. T. Sakai (1896) mentioned the migration of birds at Kitasōma, northern Hondo. A. Owston (1898) reported a group of Micropus pacificus procificus at Odawara, Prov. Sigami at the end of $\mathrm{D}$ cember. T. Niikuni (1900-1902) mentioned the migration of birds at Aizu, Hondo. S. Murata (1900-1902) observed and mentioned the habits and migration of birds in Hokkaido. U. Ōgami (1903) reported the habits and migrations of birds at Harima. C. Ingram (1908) visited Japan and reported the result of his observations on the nidification and some migration notes on birds. T. Suzuki (1915) noted the dates of migration of Hirundo rustica gutturalis from Õtaki, Prefect. Chiba. I (1915 mentioned the migration of the ducks in the duck-decoy pond at Haneda, between Tokyo and Yokohama owned by me during the eight years. Viscount Matsudaira (1915) published his observations on the migration and habits of sea-birds, waders, etc., from Prov. Sagami, Hondo. T. Nibe (1915) wrote the habits and migration of some common birds from the Prefect. Akita, Hondo.

Among later investigators, Uchila and Nibe (1918) carried out a very detailed and valuable work in this branch of ornithology. The work is entitled "Chōrui no Watari oyoli Hanshokuki" (On the Migration and Breeding Season of Birds). It contains notes of the migrations and breeding seasons of many common birds in deiailed data from almost all parts of Japan. But, there is no notice of the migration of our shore-birds. T: Momiyama (1918) reported the birds of Tokyo city and their migrations: Kuroda (1919) published his complete work on 30 species or subspecies of shore-birds at the mouth of Rokugō River between Tokyo and Yokohama. This is the first account of the migration of this group of birds. Kuroda (1918), Enomoto (1919), Ue 1919) and Kanetsune (1920) reported on the migration and habits of swallows in Japan. The results of all these inves- 
tigations are on the contrary to those of Uchida and Nibe. S. Kumagai $(1920,1923,1924)$ mentioned the migration of birds at Wakayagi, Prefect. Miyagi. Kuroda $(1920,1923)$ mentioned the migration and other ornithological notes from Prov. Chikuzen, Kiusiu. Kanetsune (1920, 1922, 1923) published his good data on the migration, breeding-seasous, etc. of birds from the neighbourhood of Sazanami, Prov. Nagato. H. Nakao (1921) and B. Kamina (1923) noted the birds of Hiroshima city with some migration records. Kuroda (1922, 1923) and Marquis Yamashina (1924) wrote the dates of migration and habits of birds from Prov. Suruga, Hondo, and J. Hemmi (192t) reported the migration of ducks at Toyama, Hondo.

Although the birds of Japan has so long been known to the systematic ornithology, practically nothing about the detailed records on migration of our birds, and Uchida and Nibe (see auted) are among the recent authors who hare only referred to the subject.

By my present observation, I could find fact of much importance and novelty; that is, many exact migration dates are plainly seen which have hitherto been wholly unknown to among orithologists. Mostly, on the $m$ gration of ducks and shore-birds in Tokyo and its neighbururhood are very perfect even in detailed parts.

This observation was carried out in my garden at Akasaka in Tokyo, in my rilla at Haneda and at the mouth of Rokugo River, during the years 1905-1924, under the guidance' of the late Prof. Dr. Ijıma, to whom I am very much indebted. Dr. S. Uchida and others also favoured me with valuable advice. My best thanks are due to these gentlemen.

\section{The Anserine Birds.}

I have observed or obtained the following water-fowls in my duckdecoy pond at Haneda near Tokyo and its neighbourhood, during the past 16 years: 


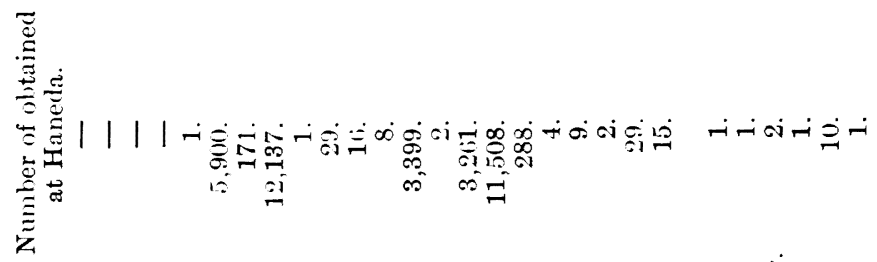
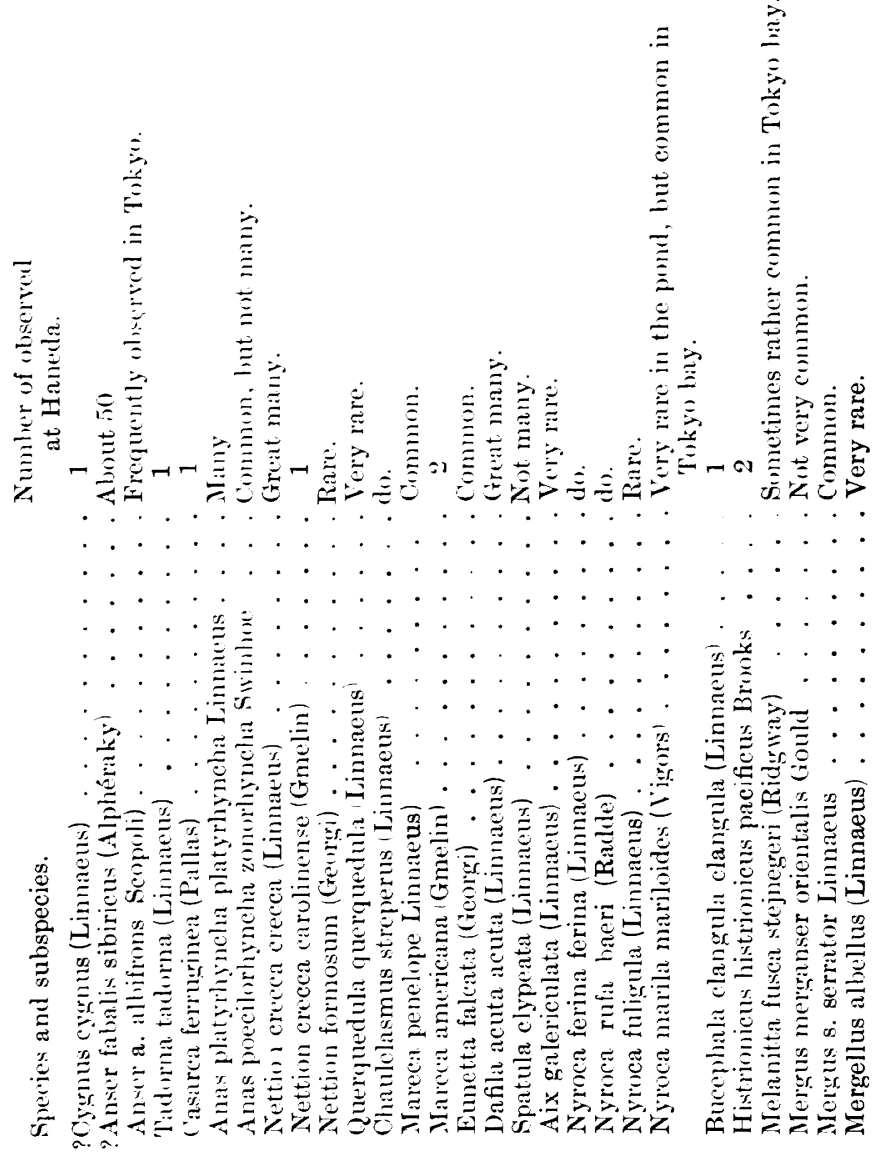

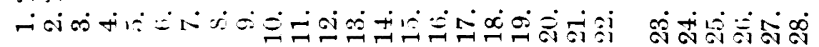


The family of ducks, geese, and swans are migratory. But some birds breed on the tropical islands, others migrate to the greater parts of the world for the purpose of feeding. Cooke writes:

"Some of the pintail ducks of Alaska and northern Asia cross the equator to the island of the South Pacific, 4,000 miles from their breeding grounds" (Distr. and Migr. Amer. Ducks, Geese, and Swans, 1906, p. $14^{\prime}$.

Among our Anserine birds, only one subspecies, Anns poecilorhyncha zonorhyncha, is the permanent resident and remains through the year near the nesting ground, and the others are all the migrants. The migration of these birds, except very rare species or stritgglers, are nearly regularly taken place yearly. Though it differs in details among specifically. From the above list only 6 species are the com non ducks of migrants in the duck-decoy pond.

\section{1. ?Cygnus cygnus (Linnaeus).*}

Whooper Swan.

I had observed a swan at the mouth of Rokugô River near Haneda, November 23. 1913, flying high in the sky and stretching its long neck. It was a swan probably belongs to the above species. It is said that a swan come to the Tokyu bay in winter yearly a time, and it also migrates to the marsh of Teganuma, Prov. Shimosa.

\section{2. ?Anser fabalis sibiricus (Alphéraky).}

Middendorff's Goose.

A flock of about 50 of a goose were always seen near the north shore of Haneda Delta in winter till then about 11 years ago (1909. But at present, it is a!l disappears, because the haunt in the shore of the goose was reclaimed. The same flock wa- also once seen in my duck pond. Frequently, a flock of a goose is now seen from winter to spring on the outer moat of the Imperial Palace in Tokyo. I have obsreved a flock of $30-40$ of a goose walking and feeding on the lawn of the outer side of the gate of the Imperial Palace! (19/II, 7/III, 10/III and 20/III, 1917).

* C. bewickii jankonskii (Alph.) was also obtained in Tokyo bay (Ogawa, 1908). 
All these geese are undoubtedly belong to the Bean geese and the greater number of them appearently belong to $A$. fabalis sibiricus and perhaps mixed with smaller $A$. frobalis serrirostris.

3. Anser albifrons albifrons (Scopoli).

White-fronted Gouse.

In early autumn a small flock of the gonse passing through Tokyo city in low flight and its calling note is frequently heard. Whether this species come down in Tokyo city in suitable places or not, though I saw a flying flock of this goose near the Imperial Palace !

The late Mr. Ogawa (1900) observed a flying group of goose near Hongo, Tokyo, from the end of October to the end of November, 1897 and he (1901) also mentioned the first arrival of goose on the high sky at the same place, Sept. 23, 1900 and only one goose was seen on the sky, March 6, 1901. These goose are probably belong to the present species. He (1908) pointed out that the goose was ottained in Tokyo bay (1908).

4. Tadorna tadorna (Linnaeus).

Sheldrake.

I had observed a male in full plumage floating in my duck-decoy pond at Haneda, 10/VI-16/VI, 1916 (Kuroda, "Dôbutsugaku Zasshi", 1916, p. 414). This is no doubt the exceptional case that it probably strays to come down in the pond such a warmer month! This species is very rare in the neighbourhood of Tokyo. Mr. Ogawa (1908) mentioned that the duck was collected in Tokyo. The latter duck was probably taken in Tokyo bay.

5. Casarca ferruginea (Pallas).

Ruddy Sheldrake.

An adult female of the sheldrake was observed at Haneda, $5 / \mathrm{XII}$, 1917 (Kuroda, "Dôbutsugaku Zasshi", 1918, p. 92), and captured in Jan. 17, 1918.

Dr. Uchida has recorded this duck was obtained at some place of Prefect. Chiba, 16/I, 1918 ("Tori", Vol. II, p. 51). Viscount Y. Matsudaira has a specimen which was collected at Koga, Prov. Shimosn, 1/I, 1912 (Uchida, op. cit., p. 52). 
This species is very rare migrant in arround the neighbourhood of Tokyo. It is probable that this duck arrives in these places only in the coldest winter !

6. Anas platyrhyncha platyrhyncha Linnaeus.

Mallard.

The mallard is one of the common ducks in the duck-decoy pond at Haneda. The following table no. 1 shows the result of observations on migration of this duck in the past 16 years.

Table no. 1 .

$\begin{array}{cc}\begin{array}{c}\text { Early date of autunu } \\ \text { arrival. }\end{array} & \begin{array}{c}\text { Last date of start } \\ \text { in spring. }\end{array} \\ 8 / \mathrm{X}, 190 \overline{0} & 26 / \mathrm{IV}, 1906 \\ 9 / \mathrm{X}, 1906 & 10 / 1 \mathrm{~V}, 1907 \\ 19 / \mathrm{X}, 1907 & 19 / 1 \mathrm{~T}, 1908 \\ 19 / \mathrm{X}, 19 \text { ' } & 7 / \mathrm{III}, 1909 \\ 10 / \mathrm{X}, 1909 & 18 / 111,1910 \\ 16 / \mathrm{X}, 1910 & 2 / 1 \mathrm{~V}, 1911 \\ 14 / \mathrm{X}, 1911 & 11 / 1 \mathrm{~V}, 1912 \\ 17 / \mathrm{X}, 1912 & 21 / 111,1913 \\ 5 / \mathrm{X}, 1913 & 8 / 111,1914 \\ 4 / \mathrm{X}, 1914 & 14 / 111,1915 \\ 5 / \mathrm{X}, 1915 & 12 / 1 \mathrm{~V}, 1916 \\ 1 / \mathrm{X}, 1916 & 26 / 1 \mathrm{~V}, 1917 \\ 7 / \mathrm{XX}, 1917 & 24 / 1 \mathrm{~V}, 1918 \\ 13 / \mathrm{X}, 1918 & \ldots \ldots \ldots \ldots \ldots \\ 3 / \mathrm{X}, 1919 & 25 / 1 \mathrm{~V}, 1920 \\ 19 / 1 \mathrm{X}, 1920 & 5 / 111,1921\end{array}$

The small flock of mallards migrates to come to the pond in autumn so early as the middle of September (exceptionally one bird arrived at $7 / \mathrm{IX}, 1917$ ) and it increases in number of youn $r$ in October. The greatest number of the duck is observable during the whole November and it begins to decrease from December to the next spring. In the end of April or rarely in March, the bird is usually disappear and absolutely absent from early in May to August or early in September.

The mallard migra tes to Tokyo yearly, but not great many. 
7. Anas poecilorhyncha zonorhyncha Swinhoe.

Dusky Mallard.

The duck and the Mandarin Duck are the permanent resident among other Anserine birds near Tokyo. For, I have no record on its migration of this resident bird at Haneda. But in winter it is very rare in my pond, though a group of this duck frequently observable on the bay, because the duck does not like to intermingle with other flocks of the different species. This is a common hird in autumn and spring in my pond but not great many. It breeds in every year arround and in the pond, from the end of April to the whole May and early in June or exceptionally as late as July. Its nest is a structure of grasses, well lined with down of the hen bird, is usually placed in the gramineous bushes on the ground near water, though sometimes on a small islet in the pond, and depositing S-13 eggs, which are ivory-white and measure about $54 \times 3.5 \mathrm{~mm}$.

In winter a large flock of this duck is seen on the outer moat of the Imperial Palace in Tokyo.

8. Nettion crecca crecca (Linnaeus).

Teal.

The teal is one of the commonnest ducks in my pond at Haneda. The table no. 2 shows the migration dates of the duck:

Table no. :-2.

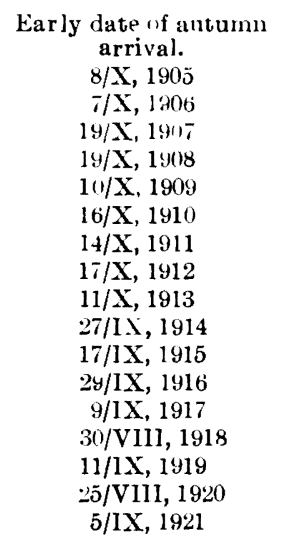

Last date of start
in spring
$3 / \mathrm{V}, 1906$
$3 / \mathrm{V}, 1907$
$11 / 1 \mathrm{~V}, 1908$
$25 / 1 \mathrm{~V}, 1909$
$15 / \mathrm{V}, 1910$
$. / \mathrm{V}, 1911$
$4 / \mathrm{V}, 1912$
$11 / \mathrm{V}, 1913$
$. / \mathrm{V}, 1914$
$9 / \mathrm{V}, 1915$
$6 / \mathrm{V}, 1916$
$18 / \mathrm{V}, 1917$
$10 / \mathrm{V}, 1918$
$\ldots \ldots \ldots \ldots$
$17 / \mathrm{V}, 1920$
$28 / \mathrm{V}, 1921$


The small flock (5-20 individuals) of the teal migrates to arrive at the pond in autumn so early as the early parts in September (exceptionally 2 or 3 birds arrived at there in 30/VIII, 1918 and $25 /$ YIII, 1920) and increase in number of young birds in Outoler. The maximum number of the duck is usually observed during the whole November and Descember. In the end of April, it begins to decrease in number but usually in May. Frequently one hundred of the teal is seen even in May and some individuals remain to the end of the month. I have observed an adult male in the pond in June 11, 1911i and another example of a teal has been found at the mouth of Rokugō River in July 31, 1916 (Kuroda, “Dôbutsugaku Zasshi", 1916, p. 414). These two examples are no doubt the exceptional cases and probably somewhat wounded. The teal breeds in one of the Kuriles and Hokkaido but it does not breed arround the neighbourhood of Tokyo! The teal is usually absent near Tokyo only from June to August except the abnormal cases.

In Tokyo city, the teal is commonly seen on the outer moat of the Imperial Palace or other places from early autumn to the end of spring. I have a small fish-pond in my house at Akasaka in Tokyo. In this place, a small group of the teal is also come down in autumn to spring. The following is the dates of autumn arrivals of the duck in this pond:-

20/IX, 1916 (only one bird was seen); 24/X, 1917 ione female was seen); $7 / \mathrm{X}, 1918$ ( 3 teals were seen). I can not mention that the exact last dates of start in spring at Akasaka.

"Is essentially a fresh-water Duck, only found on salt-water in exceptional cases " is Dresser's word. This is the truth that I have never seen a teal on sea.

9. Nettion crecca carolinense (Gmelin).

American Teal.

Two examples of adult males were as obtained in my duck pond at Haneda, Feb. 17, 1916 (Kuroda, "Dôbutsugaku Zasshi ", 1916, p. 413) and March 9, 19:21. The former is the first record that the teal was obtained in Japan. I have no record on the migration of the subspecies. 
10. Nettion formosum (Georgi).

Baikal Teal.

The handsome duck is one of the rarer species in Tokyo and its neighbourhood than in Kinsiu, where the numereous flock is seen. Very small number of the duck was obtained at Haneda during the past 16 years. I have an example of the duck captured in Tokyo city and Mr. Ogawa (1908) reported this species from Yokohama.

The following is the tahle of the teal was obtained at Haneda:

Table no. 3 .

\begin{tabular}{|c|c|}
\hline Date of collection. & Number of specimens collected \\
\hline $19 / \mathbf{X}, 1905$ & l \\
\hline $3 / \mathrm{X} 11,1905$ & 1 \\
\hline $4 / 1,1906$ & 2 \\
\hline $3 / 11,190 \bar{T}$ & 1 \\
\hline $10 / 31,1907$ & 2 \\
\hline $17 / 11,1907$ & 1 \\
\hline $8 / \mathrm{XII}, 1907$ & 1 \\
\hline November, 1908 & 1 \\
\hline 1/11I, 1909 & 1 \\
\hline $26 / \mathrm{XI}, 1910$ & 1 \\
\hline $3 / \mathrm{XI}, 1912$ & 1 \\
\hline 17/XI, 1912 & 1 \\
\hline 3/XII, 1912 & 1 \\
\hline 5/11, 1913 & 1 \\
\hline October, 1913 & 1 \\
\hline $29 / \mathrm{XI}, 1914$ & 2 \\
\hline $10 / 1,1915$ & 3 \\
\hline $26 / 1,1917$ & 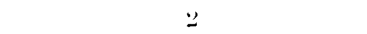 \\
\hline $15 / \mathrm{XI}, 19 \div 0$ & 2 \\
\hline $11 / 1,1921$ & 3 \\
\hline
\end{tabular}

From the above table I can state that the duck frequently migrates to the pond in small numbers. Its autumn migration probably begins from October to early in November and the last date of start in spring is probably in March

11. Querquedula querquedula (Linnaeus).

Garganey.

This beatiful duck is one of the rarer visitors to the pond at Haneda than that of the preceding duck. 
The following table shows the collected dates and number of the garganeys at Haneda:

Table no. 4.

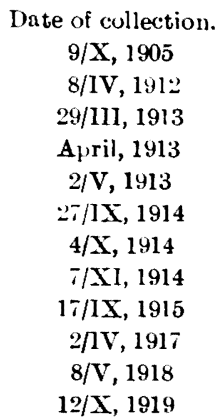

Number of specimens collected.

$$
\begin{gathered}
\text { 9/X, 1905 } \\
8 / \mathrm{IV}, 1912 \\
29 / 111,1913 \\
\text { A }_{\text {pril, } 1913} \\
2 / \mathrm{V}, 1913 \\
2 \mathrm{I} / \mathrm{IX}, 1914 \\
4 / \mathrm{X}, 1914 \\
7 / \mathrm{X}, 1914 \\
17 / \mathrm{IX}, 1915 \\
2 / 1 \mathrm{~V}, 1917 \\
8 / \mathrm{V}, 1918 \\
12 / \mathrm{X}, 1919
\end{gathered}
$$

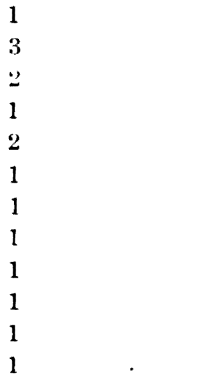

From this table, it is clearly seen that the garganey is a rare but regular migrant to my pond both in autumn and spring migrations. The autumn migration probably begins from so early as the middle of September to the early parts of November. It is probably absent during the winter season (Dec.-Feb.). The spring migration from the southern winter home to the pond probably begins from the end of March and April or even to early in May.

Mr. Ogawa (1908) reported this duck from Yokohama.

12. Chaulelasm us streperus (Linnaeus).

Gadwall.

The gadwall is a rare visitor to the pond at Haneda. The dates of collection and number of individuals obtained may be tabulated as follows :

Table no. 5 .

$\begin{array}{cc}\text { Date of collection. } & \text { Number of specimens collectted. } \\ 23 / \mathrm{XI}, 1907 & 1 \\ 26 / \mathrm{I}, 1908 & 1 \\ 16 / \mathrm{III}, 1911 & 2 \\ \text { 9/I, 1912 } & 1 \\ 3 / \mathrm{X} 11,1912 & 1 \\ \text { 6/II, 1918 } & 1 \\ \text { 3/1I, 1919 } & 1\end{array}$


The gadwall is an irregular autumn or winter vis tor to the pond. I have nothing about the migration of the duck, except the table no. 5, though I have a memory that ten of the duck was caught in a day in about 28 yea s ago (1!03?). The last example is undoubtedly an exc ptional case. Mr. Ogawa (1908) also reported the duck from Yokohama.

13. Mareca penelope (Linnaeus).

Wigeon.

The wigem is a common duck at Haneda. The table no. 6 shows the result of observations on migration of the duck in the past 16 years:

Table no. 6 .

$\begin{array}{cc}\begin{array}{c}\text { Early date of autumn } \\ \text { arrival. }\end{array} & \begin{array}{c}\text { Las1 date of start } \\ \text { in spring. }\end{array} \\ 15 / \mathrm{X}, 190 \overline{1} & 26 / 1 \mathrm{~V}, 1906 \\ 15 / \mathrm{X}, 1906 & 8 / \mathrm{IV}, 1907 \\ 19 / \mathrm{X}, 1907 & 19 / 1 \mathrm{~V}, 1908 \\ 19 / \mathrm{X}, 1908 & 18 / \mathrm{IV}, 1909 \\ 10 / \mathrm{X}, 1909 & 10 / \mathrm{V}, 1910 \\ 26 / \mathrm{X}, 1910 & 6 / \mathrm{V}, 1911 \\ 22 / \mathrm{X}, 1911 & 9 / \mathrm{lV}, 1912 \\ 17 / \mathrm{X}, 1912 & 27 / \mathrm{IV}, 1913 \\ 16 / \mathrm{XI}, 1913 & 22 / 111,1914 \\ 27 / \mathrm{X}, 1914 & 21 / 111,1915 \\ 28 / \mathrm{X}, 1915 & 29 / 1 \mathrm{~V}, 1916 \\ 29 / \mathrm{XI}, 1916 & 5 / \mathrm{V}, 1917 \\ \ldots \ldots \ldots \ldots \ldots . . & 10 / 1 \mathrm{~V}, 1918 \\ \tau / \mathrm{X}, 1918 & \ldots \ldots \ldots \ldots \ldots . \\ 24 / \mathrm{X}, 1919 & 9 / 1 \mathrm{~V}, 1920 \\ 30 / 1 \mathrm{X}, 1920 . & 17 / 1 \mathrm{~V}, 1921 .\end{array}$

The small flock of wigeons migrates to the pond in autumn so early as in October (exceptionaly some individuals arrived at 27/IX, 1914) and it increases in number from the end of October to the whole Novembirr and usually decreases from December. Some birds only remain during the winter. In March, a flock again arrives to the pond and 
usually decreases from the end of April and wholly disappears early in May, though in some years, the flock not again arrives in March.

The wigeon migrates in small number to Tokyo regularly. Mr. Ogawa (190s) mentioned it from Yokohama.

\section{Mareca americana (Gmelin).}

American Wigeon.

The widgeon sometimes arrives to the pond at Haneda in solitary, perhaps it intermingles with a Hock of $M$. penelope. The first record of the duck obtained at the locality is in Dec. 4, 1908 (Kuroda, "Dobutsugaku Zasshi ", 1909, p. 145; id., Auk, 1920, p. 311). I have another example of the duck captured at the same locality. Jan. 16, 1918 (Kuroda, "Tori", Vol. II, No. 6, p. 52). Also three individuals were obtained at Shinhama, Prefect. Chiba, along the sea-shore of Tokyo Bay in the autumn of 1919. All these eximples are males and not a female was recorded from Japan.

\section{Eunetta falcata (Georgi).}

Falcated Teal.

This remarkable duck is one of the common species at Haneda. The following table shows the result of migration records of the duck in the past 16 years:

Table no. 7 .

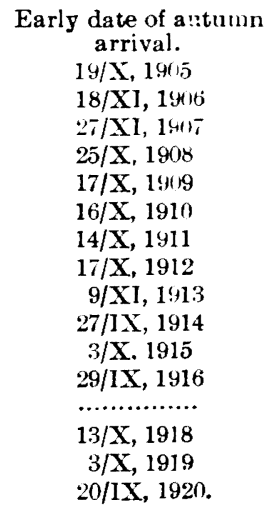

$$
\begin{gathered}
\text { Last date of start } \\
\text { in spring. } \\
6 / \mathrm{V}, 1906 \\
24 / 1 \mathrm{~V}, 1907 \\
19 / 1 \mathrm{~V}, 1908 \\
25 / \mathrm{lV}, 1909 \\
15 / \mathrm{V}, 1910 \\
30 / \mathrm{IV}, 1911 \\
28 / \mathrm{IV}, 1912 \\
11 / \mathrm{V}, 1913 \\
16 / \mathrm{IV}, 1914 \\
2 / \mathrm{V}, 1915 \\
6 / \mathrm{V}, 1916 \\
9 / \mathrm{V}, 1917 \\
6 / \mathrm{V}, 1918 \\
\ldots \ldots \ldots \ldots \ldots . \\
12 / \mathrm{V}, 1920 \\
3 / \mathrm{V}, 1921 .
\end{gathered}
$$


The migration of the duck is very similar to that of Mareca penelope, though in March or April a flock of the duck much more arrives. The autumn migration begins at early in October (exceptionally some birds arrived at $2 \tau / I X, 1914,29 / \mathrm{IX}, 1916$ and $20 / \mathrm{IX}, 1920)$. It increases in number from the end of October to the November and usually decreases from December. In some years, some birds remain during the winter. In March or April, a flock again arrives to the pond and usually decreases from the end of April and wholly disappears in the middle of May.

The duck was not observed in Tokyo city until in the autumn of 1928. It is a frequenter of fieshwater, though sometimes in the bay of Tokyo. Mr. Ogawa (1908) reported it from Yokohama. Next to Nettion crecca crecca, the species is always remain so later in the spring. I have observed a group of the duck (about .0 birds) floating on Teganuma, Prefect. Chiba, $26 / \mathrm{V}, 1915$. But it is probably not breed there.

16. Dafila acuta acuta (Linnaeus).

Pintail.

The pintail is the most common and most numerous duck as the winter resident. Following table shows the result of the observations on migration of the duck at Haneda during the 16; years:

Table no. 8.

\begin{tabular}{|c|}
\hline $\begin{array}{l}\text { Early date of autumn } \\
\text { arrival. }\end{array}$ \\
\hline $21 / \mathrm{X}, 1905$ \\
\hline $17 / \mathbf{X}, 1906$ \\
\hline $19 / \mathrm{X}, 1907$ \\
\hline $19 / \mathrm{X}, 1908$ \\
\hline $26 / X, 1909$ \\
\hline $5 / \mathrm{XI}, 1910$ \\
\hline $22 / \mathbf{X}, 1911$ \\
\hline 3/XI, 1912 \\
\hline $21 / \mathrm{X}, 1913$ \\
\hline $4 / X, 1914$ \\
\hline $26 / 1 X, 1915$ \\
\hline i/XI, 1916 \\
\hline ...................... \\
\hline $13 / X, 1918$ \\
\hline 16/X, 1919 \\
\hline $1 y / 1 X, 1920$. \\
\hline
\end{tabular}

Last date of start
in spring.
$14 / 1,1906$
$5 / 111,1907$
$19 / 1 \mathrm{~V}, 1918$
$7 / 111,1909$
$1 / 1 \mathrm{~d}, 1910$
$26 / 111,1911$
$17 / 111,1912$
$27 / 1 \mathrm{~V}, 1913$
$8 / 111,1914$
$27 / 111,1915$
$30 / 111,1916$
$28 / 111,1917$
$14 / 111,1918$
$\ldots \ldots \ldots \ldots \ldots \ldots$
$25 / 1 \mathrm{~N}, 1920$
$25 / 111,1921$.


The duck begins to migrate to the pond at the middle of October (exceptionally some individuals arrived at so early as 19/IX, 1920; 26/IX, $1915 ; 4 / \mathrm{X}, 1914)$ in a very small number and its numerous flock is seen from the middle of November! From December to January, it is always observable more than ten thousand birds fill in the pond. It begins to decrease in number from early in February and become very perceptibly few in number in March, and almost disappears in April, though exceptionally 2 or 3 birds still remain so later as the end of April (27/IV, 1913 and $25 / \mathrm{IV}, 1920$ ).

A few numbers of the duck visit Tokyo city. It was obtained at Yokohama (Ogawa, 1908).

17. Spatula clypeata (Linnaeus).

Shoveller.

This curious duck is rather common but not great many birds are seen in the pond. Its migration records during the 16 years may be tabulated as follows:

Table no. 9.

\begin{tabular}{|c|c|}
\hline $\begin{array}{l}\text { Early date of antumn } \\
\text { arrival. }\end{array}$ & $\begin{array}{l}\text { Last date of start } \\
\text { in spring. }\end{array}$ \\
\hline $15 / \mathrm{X}, 1905$ & $26 / \mathrm{llI}, 1906$ \\
\hline $17 / \mathrm{X}, 1906$ & $24 / 1 \mathrm{~V}, 1907$ \\
\hline $19 / \mathrm{X}, 1907$ & $18 / 1 \mathrm{~V}, 1908$ \\
\hline $25 / X, 191.8$ & $4 / 1 \mathrm{~V}, 1909$ \\
\hline $2 / \mathrm{XI}, 1909$ & $1 / \mathrm{V}, 1910$ \\
\hline $19 / \mathrm{X}, 1910$ & $21 / 1 \mathrm{~V}, 1911$ \\
\hline $14 / X, 1911$ & $26 / 1,1912$ \\
\hline $8 / \mathrm{XI}, 1412$ & $11 / \mathrm{V}, 1913$ \\
\hline $5 / X, 1913$ & $22 / 11,1914$ \\
\hline $26 / \mathrm{XI}, 1914$ & $14 / 11,1915$ \\
\hline 12/XI, 1915 & $26 / 11,1916$ \\
\hline 30/X11, 1916 & ……......... \\
\hline .................... & I/V, 1918 \\
\hline $24 / X, 1918$ & …................ \\
\hline 19/X, 1918 & $5 / 1,1920$ \\
\hline $30 / 1 X, 19:()$ & $8 / 1 V, 1921$ \\
\hline
\end{tabular}


The autumn migration of the duck begins at the middle of October in a very small group, exceptionally some birds arrived so early as in end of September (30/IX, 1920) and sometimes so later as in the end of December (30/XII, 1916). It is usually rather common in November or December, though it differs yearly. But it always decreases in number from January to February and some birds only remain in winter. It again arrives to the pond from March to April and some individuals still remain till early in May. The start in spring from this pond to its northern breeding ground is probably very irregular. This fact is clearly seen from the above table.

The shoveller sometimes visits to the outer moat of the Imperial Palace in Tokyo in a small number (winter to spring). It was collected at Yokohama (Ogawa, 1908).

18. Aix galericulata (Linnaeus).

Mandarin Duck.

I have observed the duck at Haneda, Oct. 4, 1918. Two pairs of the duck were obtained at the same locality, Nov. :2, 1918. Another pair has observed at the end of November of the same year. A male arrives here Dec. 2, 19:20.

The mandarin duck inhabits generally in rivers and lakes in the mountainous region, though sometimes come down to the pond near seashore, but rarely. It was obtained in Tokyo and Mr. Ogawa (1908) reported it from Yokohama. The duck breeds in Hondo, Japan and also in Tokyo where it is a resident !

19. Nyroca ferina ferina (Limnaeus!.

Pochard.

The pochard is one of the rarest birds at Haneda. The following is the table of the pochard was obtained at Haneda: 
Table no. 10 .

$\begin{array}{lc}\text { Date of collection. } & \text { Number of specimens collected. } \\ \text { 6/XI, } 1908 & 1 \\ 16 / \mathrm{I}, 1909 & 2 \\ 15 / \mathrm{XI}, 1909 & 1 \\ \text { December, } 1910 & 1 \\ 18 / \mathrm{I}, 1911 & 1 \\ 2 \text { / } \mathrm{XI}, 1912 & 1 \\ 14 / \mathrm{XII}, 1912 & 2\end{array}$

The autumn migration probably begins at early in November. The duck is essentialy a winter resident at the locality, though the number is always very few. I have no record of the duck in the spring migration.

It is rather common in Teganuma, Prov. Shimosa. Mr. Ogawa (1908) reported this duck from Yokohama.

20. Nyroca rufa baeri (Radde).

Baer's Duck.

This duck is the rarest b:rd in the pond at Haneda. Only two males were obtained during the 16 years:

Table no. 11.

$\begin{array}{lc}\text { Date of collection. } & \text { Number of specimens collected. } \\ 23 / \mathrm{XI}, 1908 & 1 \\ \text { November, } 1909 & 1\end{array}$

The autumn migration probably begins during in November in a very small number, and visiting to Japan. I have a female specimen obtained at Teganuma, Prov. Shimosa.

There are four examples in the Pryer collection from Yokohama (Seebohm, 1s90). It has occurred both in Hokkaido and on the main island, but probably only in winter (Blakiston and Pryer, 1878).

\section{Nyroca fuligula (Linnaeus). \\ Tufted Duck.}

The duck is one of rather rare birds at Haneda, but not very rare. rIts ecord of collection may be tabulated as below: 
Table no. 12.

\begin{tabular}{|c|c|}
\hline Date of collection. & Number of epecimens collected. \\
\hline I/XI, 1908 & 1 \\
\hline $23 / \mathrm{XI}, 1908$ & 1 \\
\hline 24/XII, 1908 & 1 \\
\hline November, 1901 & 2 \\
\hline April, 1911 & 1 \\
\hline 30/XI, 1913 & 3 \\
\hline December, 1913 & 2 \\
\hline $31 / \mathrm{X}, 1914$ & 4 \\
\hline 1/XI, 1914 & 1 \\
\hline $7 / \mathrm{XI}, 1914$ & 1 \\
\hline October, 1915 & 1 \\
\hline 12/XI, 1915 & 2 \\
\hline 19/XI, 1915 & 1 \\
\hline 29/XI, 1915 & 1 \\
\hline April, 1916 & 2 \\
\hline November, 1916 & 1 \\
\hline $25 / 1 \mathrm{I}, 1917$ & 1 \\
\hline 19/XI, 1918 & 1 \\
\hline 18/XII, 1918 & 2 \\
\hline $27 / \mathrm{XI}, 1920$ & 4 \\
\hline $311 / \mathrm{XI}, 1920$ & 1 \\
\hline $8 / \mathrm{XII} .1920$ & 2 \\
\hline $14 / \mathrm{XII}, 1920$ & 1 \\
\hline $31 / \mathrm{XII}, 1920$ & 1 \\
\hline $5 / \mathrm{I}, 1921$ & 1 \\
\hline $11 / I, 1921$ & 1 \\
\hline $12 / I, 1921$ & 1 \\
\hline 15/I, 1921 & 2 \\
\hline
\end{tabular}

The autumn migration begins at the end of October or early in November. The spring migration, start from the pond to the north, is probably taken place at the early parts of April. It is a winter resident.

Blakiston and Pryer (1878) have stated that the duck is a spring and autumn visitor to Hokkaido, and may possibly breed there, but in 
Southern Japan it is only known as a winter visitor. Scebohm (1890) reported the duck from Yokohama and Mr. Ogawa (1908) also mentioned it in his list from the last locality.

:2. Nyroca marila mariloides (Vigors).

Eastern Scaup Duck.

The duck is rarer bird than the tufted duck at Haneda. The collected date and number may be tabulated as follows:

Table no. 13.

$\begin{array}{lc}\text { Date of collection. } & \text { Number of specimens cullected. } \\ 19 / \mathrm{XI}, 1908 & 1 \\ 21 / \mathrm{XI}, 1908 & 1 \\ 23 / \mathrm{XI}, 1908 & 1 \\ 2 / / \mathrm{XI}, 1908 & 1 \\ 31 / \mathrm{X} 11,1910 & 1 \\ 31 / \mathrm{X}, 1914 & 2 \\ 1 / \mathrm{XI}, 1914 & 1 \\ 29 / \mathrm{XI}, 1914 & 1 \\ 15 / \mathrm{X} 111,1914 & 1 \\ 3 / \mathrm{I}, 1915 & 1 \\ 26 / 111,1915 & 1 \\ 2 / \mathrm{XI}, 1915 & 1 \\ 5 / \mathrm{XI}, 1915 & 1 \\ 2 / \mathrm{XI}, 1918 & 1\end{array}$

The autumn migration begins at the end of October (exceptionally arrived at $3 / \mathrm{X}, 1918$ ) to the middle of November. The spring migration, start from the pond to the northern breeding ground, is probably taken place at the middle of April.

The duck, like the preceding species, is essentially a saltwater species or a bay bird so that it is rare in the pond! I observed a group of this duck (about two hundred) at Tsurumi near Yokohama, April 13, 1913. This is one of the very common species in Tokyo bay (near Chiba) in winter to spring! Seebohm (1890) reported the duck from Yokohama and Mr. Ogawa (1908) also mentioned it from the same locality. 
23. Bucephala clangula clangula (Linnaeus).

Golden-Eye.

An example of the duck was obtained in the pond at Haneda, Jan. 31, 1909. I have a few records of the duck at Haneda, though Seebolım (1890) stated that there are eight examples in the Pryer collection from Yokohama. Mr. Ogawa (1908) also reported the duck from the latter locality. I think the duck is more numerous in the northern Kiusiu (Prov. Chikuzen) than in the Tokyo Bay. I observed and collected many examples in the Prov. Chikuzen.

24. Histrionicus histrionicus pacificus Brooks.

Pacific Harlequin Duck.

A specimen of the duck was obtained by me near Kawasaki, Jan. 31, 1915, from two birds. Seebohm (1890) mentioned two examples of the duck from Yokohama and Mr. Ogawa (1908) reported it from the same place.

"The duck is a winter visitor to the Japanese Islands; extremely abundant on the Kuriles, less so in Yezzo, and least so in the more southerly islands "(Blakiston \& Pryer, 1882). This theory is no doubt truth. I have an example of the duck obtained in the Prov. Chikuzen, North Kiusiu. It is probably the southernmost distribution of the northern species! It probably migrates from Korea.

25. Melanitta fusca stejnegeri (Ridgway).

Kamtschatkan Scoter.

Once I collected an example of the duck from a numerous flock of the same bird at the offing of Kawasaki, March 25, 1909. Another example of the duck was captured in my pond at Haneda, October 17, 1920. This is no doubt the sea or bay duck and very rarely come to the fresh-water. Seebohm (1890) and Mr. Ogawa (1908) reported it from Yokohama.

26. Mergus merganser orientalis Gould.

Eastern Goosander.

An example of the bird was obtained at the mouth of Rokugō River, Haneda, April 12, 1918. This is the rarer bird than the next species at 
the locality. The migration is probably so later as the middle of Dicember and still remain till the end of April (a femal of the bird was seen at my pond on the 29th of April, 1913). I collected a specimen at Koshiba, near Yokohama. All thes specimens apparently belong to the present subspecies.

27. Mergus serrator serrator Linnacus.

Red-breasted Merganser.

The merganser is a rather common bird near the mouth of Rokugō River and sometimes come to my pond also. The date of collection and number may be tabulated as below:

Table no. 14.

Dat of collection. Iocality and number of specimens collected.

$\begin{array}{lll}25 / 111,199 & 1 \text { (offing of Kawasaki). } \\ 11 / 1 \mathrm{~V}, 1912 & 1 \text { (offing of Haneda). } \\ 26 / 111,1913 & 1 \text { (d). } \\ \text { 10/1V, 1913 } & 1 \text { (offing of Kawasaki). } \\ 8 / 111,1914 & 1 \text { (Haneda). } \\ 30 / \mathrm{XII}, 1915 & 1 \text { (offing of Haneda). } \\ 2 / 1 \mathrm{~V}, 1916 & 4 \text { (d do. }\end{array}$

The autumn migration of the bird is not much differ from that of the goosander. That is, the bird arrives to the Tokyo bay near Haneda from the middle of November $(18 / \mathrm{XI}, 1917 ; 4$ birds were seen) to the middle of December and usually remains till the end of April or sometimes still in May.

The present form and the preceding bird are essentially winter visitors to the Tokyo bay, and the present form makes a flock of about 10-30 individuals near the sea-shore of Kawasaki or Haneda and sometimes offing of both.

Six specimens were obtained and preserved in the Pryer collection from Yokohama (Seehohm, 1890) and Mr. Ogawa (1908) noted it from the same place.

28. Mergellus albellus (Linnaeus'.

Smew.

The smew is a very rare visitor to the pond at Haneda. I observed a 
female at the locality on the 25th of January, 1918 (Kuroda "Tori ", Vol. II, p. 53) and a nother female was obtained there on the 16th of November of the same year.

Blakiston and Pryer (1878) reported the bird from the Yokohama game-market on winter, Seebohm (1890) mentioned it from Yokohama and Mr. Ogawa (1908) also noted it from the same place. I have a few examples from Teganuma, Prov. Shimosa in February, 1917, 1930 and 1931.

The species nodoubt the winter visitor to the neighbourhood of Tokyo.

\section{The Ardeine Birds.}

I have observed or obtained the following herons and egrets im my duck-decoy pond at Haneda near Tokyo and its neighbourhood:

Species and subspecies. Number of observed at Haneda

1. Ardea cinerea rectirostris Gould . . . Rare.

2. Egretta alba modesta (Gray) . . . . Very rare.

3. Erretta intermedia intermedia (Wagler) . Common and breed.

4. Egretta garzetta garzetta (Linnaeus) . . . Common and resident.

5. Bubulcus ibis coromandus (Boddaert) . . Very rare, but breed.

6. Butorides striatus amurensis Schrenck . . A few in summer, but breed.

7. Nycticorax nycticorax nycticorax (Linn-

aeus) . . . . . . . . Great many and resident.

8. Gorsakius goisagi (Temminck) . . . . Only one observed.

9. Ixobrychus sinensis sinensis (Gmelin). . . Common and breed.

Among these ardeine birds, only two species, Egretla garzetta garzetta and Nycticorax nycticorax nycticorax, are the resident and the others are all of the migrants.

1. Ardea cinerea rectirostris Gould.

Eastern Heron.

The heron is a rare visitor to the pond or the mouth of Rokugo River, Haneda, though it never breeds there. It visits in these places usually in summer and autumn or exceptionally in winter. I have seen seven herons of the species at the mouth of the river from August, 1918 to October 3rd of the same year. 
Seebohm reported the heron from Yokohama (1890), and Mr. Ogawa (1908) also noted it from the same locality. Dr. Uchida informed me that the heron regularly breeds on the trees at Kashima, Prov. Hitachi, Hondo. Rather common at Shinhama, Pref. Chiba.

2. Egretta alba modesta (Gray).

Japancse Great White Egret.

The egret is a very rare visitor to the pond as well as the coast of Haneda in solitary in spring or summer. An example was seen in my pond at Haneda, June 30, 1920.

The large egret is now regularly breeding near Soga, Prov. Kazusa. There is a temple called "Daiganji" where many large trees are grown. Here is a fuvorite nesting-place of the egret. I have observed some birds nesting near the top of trees, June 3, 1915.

The spring migration of the egret to the locality and its neighbourhood is said to be from the end of March and it wholly disappears at the end of August.

There are two forms of the large egrets in Japan, and the both forms were reported from Tokyo and Tokyo Bay. Seebohm's statement (1890) in the following word is the truth. "Both races of the Great White Egret appear to visit Japan, the Eastern race as a common summer visitor, the Western race as a more or less accidental winter visitor."

3. Egretta intermedia intermedia (Wagler).

Plumed Egret.

The egret is a common summer visitor to the pond at Haneda from the spring of 1919. The migration recorls of the bird as follows:

Table no. 15.

$\begin{array}{cc}\begin{array}{c}\text { Date of arrival } \\ \text { in spring. }\end{array} & \begin{array}{c}\text { Date of start } \\ \text { in antumn. }\end{array} \\ \text { Niddle of April, } 1: 19 & 30 / \mathrm{V} 111,1919 \\ 17 / \mathrm{IV}, 1920 & \ldots \ldots \ldots \ldots \ldots . . \\ 1: 1 / 1 \mathrm{~V}, 1921 & 23 / 1 \mathrm{X}, 1921 \\ 13 / \mathrm{IV}, 1922 & 3 / 1 \mathrm{X}, 1922 \\ \ldots \ldots \ldots \ldots \ldots & 15 / \mathrm{IX}, 1923 \\ 4 / 1 \mathrm{~W}, 1924 & \ldots \ldots \ldots \ldots \ldots . .\end{array}$


The bird arrives in a small number to the pond at the middle of April or rarely in early part of the some month and starts there at the end of August. I have observed nesting on the pine trees at the locality in a colony of 200-300. It breeds from the end of April to July. The eggs, 4 in number, are blue in deep or pale coloured and measure about $52 \times 37 \mathrm{~mm}$.

A colony of the subspecies regularly bred at the duck-decoy pond at O'tsuka in Tokyo which was possessed by Marquis Date. In few years ago from 1924, the pond was reclaimed and the trees, where the egret is nested, were all cut down so that the bird can not breed there. The colony of the egret removed from Ōtsuka to my pond at Haneda from the spring of 1919 ! The breeding season at Ōtsuka is said to be wholly ayree with that of at Haneda.

Seebohm (1890) and Mr. Ogawa (1908) mentioned it from Yokohama.

\section{Egretta garzetta garzetta (Linnaeus).}

Little Egret.

The little egret is the resident bird at Haneda.

The colony about 50-60 of the egrets regularly breed on the pine trees or on the bamboo forest arround the pond. It breeds from late in April $(25 / \mathrm{IV}, 1921)$ to early in June, usually 5 but occasionally 4 or 6 eggs are deposited, which are uniform bluish and measure about $48 \times 30 \mathrm{~mm}$.

Eight examples of the egrct in the Pryer collection from Yokohama (Seebohm, Ibis, 1879, p. 27) and Mr. Ogawa (1908) reported it from Tokyo. Frequently, I have seen the egret on the moats in Tokyo city, in autumn to winter ( 2 egrets were seen by me on the moat near Hibiya Park, 3/X, 1917-11/X, 1917). In spring, it also remains in Tokyo. An egret visited to my pond in garden at Akasaka, 28/III, 1915.

5. Bubulcus ibis coromandus (Boddaert).

Eastern Buff-backed Heron.

The present bird is a very rare summer visitor to the pond at Haneda. A pair of the species arrived at the locality in summer about 27 years ago, but did not breed there. Two pairs of the bird visited to the place in summer of 1919, and each of them finaly bred. The migration record are as follows: 
Table no. 16.

$\begin{array}{cc}\begin{array}{c}\text { Date of arrival } \\ \text { in spring. }\end{array} & \begin{array}{c}\text { Date of start } \\ \text { in autumn. }\end{array} \\ 6 / \mathrm{VI}, 1919 & 3 / 1 \mathrm{X}, 1919 \\ 1 / \mathrm{VI}, 1919 & 25 / 1 \mathrm{X}, 1919 \\ 15 / \mathrm{V}, 1920 & 5 / \mathrm{VI1I}, 1921) \\ 8 / \mathrm{V}, 1921 & 21 / \mathrm{V} 111,1921\end{array}$

From this few data I may safely state that the b:rd arrives here as nesting place from the middle of May to the middle of June and starts to the southern home from early in September to the end of the same month.

It is said that the bird was rather common around the neighbourhood of Tokyo about 25 ycars ago.

Seebohm (1S!10) reported four examples of the bird from Tokyo and Mr. Ogawa (1908) mentioned it from the same place.

6. Butorides striatus amurensis Schrenck.

Amur Green Heron.

The heron is essentially a summer visitor in very fow individuals to the pond at Haneda, though it breeds there. The careful observations on its migration data at Haneda may be tabulated as below:

Table no. 17 .

$\begin{array}{cl}\begin{array}{c}\text { Date of arrival } \\ \text { in spring. }\end{array} & \begin{array}{l}\text { Date of start } \\ \text { in autumn. }\end{array} \\ 2 \tau / \mathrm{V}, 191 \mathrm{t} & \text { Early in Oct., } 1917 \\ 5 / \mathrm{Vl}, 1918 & : 5 / \mathrm{IX}, 1918 \\ 10 / \mathrm{V}, 1920 & \ldots \ldots \ldots \ldots \ldots . . .\end{array}$

The spring migration takes place from early in May to early in June and the autumn departure begins from the end of September to early October.

The heron migrates to Tokyo also. At my house in Tokyo (Akasaka), I obtained the following result.

Table no. 18.

Date of arrival
in spring.
……........
$28 / \mathrm{V}, 1917$

Date of start

in auturnn.

23/X, 1909

4/X, 1017 
The table wholly coincides with that of no. 17 , excepting that the heron remains till the end of October.

This bird migrates to the mouth of the Baniu River, Prov. Sagami at latest at early June, for I obtained it at th 3 last locality on the 11th of June, 1917.

It breeds on pine trees around the pond at Haneda from May to probably August, and deposits pale bluish green eggs, 3 to 5 in number in a clutch, which measure about $41 \times 30 \mathrm{~mm}$.

This bird was not reported from Tokyo by Seebohm or Ogawa.

7. Nycticorax nycticorax nycticorax (Linnaeus).

Night Heron.

The night heron is a resident bird at Haneda like the little egret, though a majority of the bird appears to remove from this place to other parts in winter. But many of the bird come back on the end of March or early in April on account of their nesting.

The breeding time is from end of March to August, about two thousand of the heron inhabiting the favorite nesting place. Its nest on pine trees consist of twigs and its eggs, usually 4 to 5 in a clutch, are deposited, and are uniform pale grcenish blue, and measure abot $63 \times 35$ $\mathrm{mm}$.

Seebohm (1890) reported it from Yokohama and Ogawa (1908) mentioned it from Prov. Musashi.

The heron also is a partially resident in Tokyo and its ricinity, making its nest there.

8 Gorsakius goisagi (Temminck).

Japanese Night Heron.

Only a single bird was observed at Haneda.

Seebohm (1898) reported it from Yokohama and Ogawa (1908) also noted it from the same place.

9. Ixobrychus sinensis sinensis (Gmelin).

Chinese Little Bittern.

The little bittern is a common summer visitor to the pond at Haneda. The migration records of the bird are as follows: 
Tuble no. 19.

$\begin{array}{cc}\begin{array}{c}\text { I) ate of arrival } \\ \text { in spring. }\end{array} & \begin{array}{c}\text { Date of start } \\ \text { in autumn. }\end{array} \\ 22 / \mathrm{V}, 1915 & \ldots \ldots \ldots \ldots \ldots \\ 15 / \mathrm{V}, 1917 & 4 / \mathrm{X}, 1917 \\ 22 / \mathrm{V}, 1915 & 9 / \mathrm{X}, 1918 \\ \ldots \ldots \ldots \ldots \ldots & 30 / 1 \mathrm{X}, 1919 \\ 21 / \mathrm{V}, 1920 & \ldots \ldots \ldots \ldots \ldots\end{array}$

The bird comes to the pond at the middle or end of May and starts from there on the end of September or early in October. I have seen a bird captured near Tsurumi Station so later as early in January (10/I, 1917). The example is evidently an exceptional case. The bird does usually not occur in winter around Tokyo, though it is said that a few bird winters in Kiusiu, probably owing to young ase. At Haneda it breeds in June and July, depositing 4 to 6 eggs in a nest which is made of reeds and bamboo-leaves.

The eggs are white with bluish tinge and measure about $33.5 \times 24.5$ $\mathrm{mm}$. Seebohm (1890) reported it Yokohama.

[To be continued.]

\section{樺太產ンマフクロフの一新亞種に就て}

理學博士黑田長禮

Bubo blaki:toni karafutonis, subsp. nov.

カラフトシマフクロフ（渐棌）

記载 北游道產シマフクロフに近似するも背面一柡に暗色几富み殊に 䧻及耳犽にありて然り。後者は暗裀色にしてシマフクロフの如く淡灰褐色 ならす。頭頂、上頸及後䫫の黑色縱班は其幅著しく狭し。腹面の地色も亦

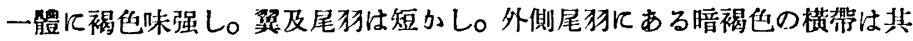

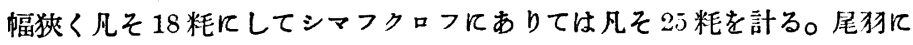
ある淡色帶は 8-9 條を有しシマフクロフの如く 7-8 保にあらす。

基型標本法大正八年一月樺太にて探集の成鳥(性不明)なり。黑田標本 番號 4200 